\section{Ethical Lingua}

Journal of Language Teaching and Literature

ISSN 2355-3448 (Print)

ISSN 2540-9190 (Online)

Volume 5, Number 1, February 2018 pp. $95-109$

\title{
Preserving Local Culture through Digital Comics
}

\author{
Tri Mulyati ${ }^{\star 1} \&$ Dhalia Soetopo ${ }^{2}$ \\ *mulyati29@uniba-bwi.ac.id \\ 1,2Universitas PGRI Banyuwangi, Indonesia \\ Received : 16 November 2017; Accepted : 29 January 2018 \\ DOI : https://doi.org/10.30605/ethicallingua.v5i1.697
}

\begin{abstract}
Digital environment offers teachers and students with a plethora of information and resources for learning. Nowadays, students who are mostly digital natives are used to utilizing technology in their daily life. This condition should make teachers as technology leaders responsible to provide a good learning environment where the students are involved in their own learning and that best suits to them in in a particular context. Therefore, this study aimed at developing local culture based digital comics for narrative reading comprehension and inserting local culture of Banyuwangi in English language teaching. This study followed the research and development design adapting the pattern developed by Borg and Gall. Based on the result of need analysis administered to students in class VIII of SMPN 1 Kalipuro, Banyuwangi, the product was developed by inserting local culture content into narrative texts in the form of digital comics. The digital comics had two titles: The Dance Competition and The Legend of Banyuwangi. The product was validated by the experts and tried out to the students. The result showed that the local culture based digital comics were applicable to be used in the teaching and learning narrative text reading comprehension.
\end{abstract}

Keywords: culture; digital comics; learning autonomy; R \& D 


\section{Introduction}

The use of materials and media in English language teaching takes significant roles. Instructional materials are main component in English language teaching (Richard, 2001). They provide the basis for the content of the lesson, the balance of skills taught, and the kinds of language practice. Cahyono \& Megawati (2013) explain that materials deal with what the teachers teach while media is a tool the teachers use to teach. Material are like ingredients which are served for cooking whereas media is like the utensils used to transform the ingredients into ready served meals. Because of that, the teachers need to use instructional materials as the primary teaching resource and use media to deliver the instructional materials effectively. Besides, for the learners, instructional materials are the major source to achieve the objectives of instructional process. And, the most important thing is that Instructional materials are one of factors fostering the learners' learning autonomy.

The learning autonomy refers to the learners' ability to be responsible for their own learning (Holec, 1981 as cited in Ivanovska, 2015). Being autonomous means that the learners are able to cope with these things i.e. "working independently, collaborative learning, problem solving, using resources, decision making, and setting and determining learning goals" (Nguyen et al., 2011). In short, the learners independently selecting the materials to learn are called autonomous learners. However, this ability is strongly influenced by the learning environment where the learners learn. Nguyen et al. (2011) further explained that the learning environment will shape the learners' learning style. The learning style they have will determine how productive the autonomous learning works. For example, the learning environment with the availability of good materials will lead the learners to independently use them for their own learning. Thus, the teachers are responsible to provide a good learning environment where the students are involved in their own learning and that best suits to them in a particular context.

There are three types of contexts, namely, linguistics context, situational context, and cultural context (Song, 2010). When communicating, people have to consider these contexts. Linguistic context is a relation among words, phrases, and sentences that creates a meaning. It involves syntagmatic and morphological interpretation of the text elements. Situational context is a knowledge owned by language users about everything that is related with environment, place, time when the language is used. Cultural context is knowledge of culture, customs, and historical background of society where the language is used. From this definition, it can be concluded that contexts are very important since they help language users to interpret meanings. 
The three contexts above show that a culture cannot be separated from those who learn or use a language for communication. Spradley (as cited in Clandfield, 2008) defines a culture into three groups: cultural artifacts, cultural knowledge, and cultural behavior. Cultural artifacts are things that were made and used by people. Cultural knowledge is everything that becomes people knowledge, and cultural behavior is people behavior and activities. On the other hand, Sharifian (as cited in Xu, 2013) defines a culture as event schemas, role schemas, image schemas, proposition schemas and emotion schemas. Event schemas are related with an experience of a certain event. For example, a learner who is involved in Tumpeng Sewu event in Banyuwangi will have event schema about Tumpeng Sewu celebration. Role schemas are knowledge about rule and norms in a society which is implemented in the form of knowledge about how to behave based on where he is from. Image schemas are symbols which are visualized and become a representative of social experience and physical condition. Proposition schemas are abstractions which play a role as a model of thought and behavior while emotion schemas are a complex combination between feeling and experience about certain events and situations. In short, the cultural knowledge plays a significant role in a language learning success. In the end of learning process learners who have master a certain language will not use a language as a mean of communication, but they will use it for expanding new cultural knowledge.

Considering to the interrelated relation between language and culture and the need of providing a good learning environment for building the learning autonomy, it is necessary to use English instructional materials with local culture contents. According Genc \& Bada (2005) in the era of toleration on the difference of ideology, religion, and culture, language learners have to know not only the foreign culture but also their own culture. By having a good understanding on their own culture, the language learners will be able to decide whether a new culture can be adopted, adapted, or rejected. From a different point of view, Royani (2012) explained that the use of authentic materials in English language teaching causes difficulties and confusion among learners because of the different environment and context between materials and the language learners. That is why in the development of English language teaching, it is needed to insert the value of Indonesia local culture. This is important in order to preserve nation cultural identity and to motivate language learners in learning English.

However, the need of providing a good learning environment in English language teaching was not supported by the availability of English materials containing Indonesia local culture. Also, the use of media as a tool to deliver the materials to the learners still becomes an issue. Indonesia local culture which was found in English textbooks was limited on local folklore such as Malin Kundang from West Sumatra, Legend of Danau Toba from North Sumatra, and 
Tangkuban Perahu from West Java (Prasetyo, 2016). However, it seems ironic since Indonesia has a lot of local folklore in every region. For example, in Banyuwangi region, English materials should have contained the local folklore of Banyuwangi such as Legend of Banyuwangi, Tumpeng Sewu, Barong, Kebo Keboan, etc. Another issue is that an activity to deliver a local culture is only limited on a story telling activity. The teachers and learners usually tell about the story of Cinderella and Snow White. The use of high-tech media like digital comics has not been found yet. The teachers and learners usually use ready used comics of which the content may not suit to the learners' culture identity. In this digital era, the learners have involved in the global access. They are used to using computers, smartphones, and various internet features for daily need. This condition expects teachers to be a step ahead in using technology. The teaching and learning activity should not use monotone and limited activities in the classroom, but it should integrate computer and internet as a source and media for learning. In short, the materials and media used must facilitate the learning activity to happen wherever and whenever.

Based on this condition and needs, the researchers aimed at developing instructional material and media in the form of local culture based digital comics for the eighth year students of SMP Negeri 1 Kalipuro Banyuwangi. Digital comics are combination between narrative texts and digital contents. Abdel-Hack \& Helwa (2014) explain that digital comics have some benefits such as a clear and colorful visualization, sound effects, and transition effect that enable readers comprehend the story. Further, Ravelo (2013) explained that pictures in comics are designed to be interrelated and support each other so that readers can read the texts through the pictures. The use of texts in comics is a part of narrative stories. The texts are written in the conversation balloon. Sometimes, the writer substitutes the texts with simple pictures to simplify the message (Steimberg, 1977 cited in Ravelo, 2013). For example, the writer uses a bulb picture to represent a brilliant idea. The combination between pictures and texts makes reading comics interesting and stimulate readers not to stop reading.

Therefore, this study aims to develop local culture based digital comics for the eight year students of SMP Negeri 1 Kalipuro. The result of the study is expected to contribute useful English instructional materials and media for learning English, especially for reading narrative texts. Also, by developing the local culture based digital comics, it is hoped that learners can improve their reading achievement, develop their electronic literacy, love their culture, and finally become autonomous learners. 


\section{Method}

This research aims to develop local culture based digital comics as learning materials for the eighth year students of Junior high school in SMPN 1 Kalipuro, Banyuwangi. The researcher adapted Research and Development design proposed by Borg \& Gall (1983) namely, need analysis, developing preliminary form of products, preliminary field testing, product revision, main field testing, main product revision, and final product. In the need analysis stage, the data was taken using document analysis, interview, and questionnaire. These were used to collect information regarding basic competences of reading skill in English syllabus, the materials and media in English language teaching of eighth year students at SMP Negeri 1 Kalipuro and the need on local culture based digital comics for learning narrative texts. The data was analyzed in the descriptive qualitative form covering three steps of analysis: data reduction, data presentation, and drawing conclusion. Then, the result gained from the need analysis was used as the underpinning idea of developing local culture based digital comics. In the developmental stage, the data was gained through questionnaires. After the draft of digital comics had been developed, it was consulted to the material and media expert from Malang State University and the English teacher of SMPN 1 Kalipuro for validation. It was done in order to measure the quality of digital comics as the instructional media. The evaluation covers four aspects, i.e. instruction, the appropriateness of content, language, graphic, and presentation. Try out was also conducted to measure the quality of the draft from the students' point of view. Here, the students were asked to read comics and were engaged in the discussion. After that, they were asked to complete questionnaires for measuring five aspects of digital comics i.e. function, appropriateness of content, language use, attractiveness, and the difficulty level of material. After the expert validation and try out were done, the data was analyzed by using descriptive statistical analysis and revised based on the feedbacks. At last, the final product was ready to be disseminated and used.

\section{Results}

The results of the research presented in this section are the result of need analysis, the validation result of English teacher and material and media expert, and the result of try out analysis.

Based on the result of need analysis, the researcher can identify the condition of teaching and learning activities in SMPN 1 Kalipuro. The teachers used limited materials and media in the teaching of narrative reading comprehension. Instructional media such as LCD, OHP, laptop, pictures, and comics were not used in the teaching and learning process. The materials were mostly taken from worksheet and the teachers sometimes use movie and English songs. Moreover, the students depend on the dictionary when they read English 
texts. It happened because to comprehend the texts, students tend to translate sentences one by one. There were only limited students using reading strategies. They stated that they cannot identify the elements of narrative texts. The topics of narrative texts were about Cinderella, Snow white, and the like. The result also shows that students have positive perception toward the integration of technology and Banyuwangi local culture in narrative texts. Further, students explained that they need effective media to help them comprehend narrative texts like the use of electronic media. The detail description of need analysis result can be seen in appendix 1 .

Table 1. The Result of Tryout (small group)

\begin{tabular}{llrrrrrl}
\hline No & Aspects & $\begin{array}{r}\text { Number of } \\
\text { items }\end{array}$ & $\begin{array}{r}\text { Positive } \\
\text { items }\end{array}$ & $\begin{array}{r}\text { Negative } \\
\text { items }\end{array}$ & Total & Average & Criteria \\
\hline 1 & Function & $1-10$ & 37 & 13 & 50 & 0.74 & Eligible \\
2 & Attractiveness & $11-20$ & 41 & 9 & 50 & 0.82 & Very eligible \\
3 & Appropriateness & $21-30$ & 49 & 1 & 50 & 0.98 & Very eligible \\
& of content & & & & & & \\
4 & Language & $31-40$ & 29 & 21 & 50 & 0.58 & Fairly \\
5 & Difficulty Level & $41-50$ & 40 & 10 & 50 & 0.8 & Eligible \\
\hline & & TOTAL & & & 250 & 0.78 & Eligible \\
\hline
\end{tabular}

Table 1 shows that the average score of questionnaire given to five students were 0.78 . The score was in interval $0.60-0.80$. It means that digital comics were eligible to be used in the teaching and learning process of narrative reading comprehension in class VIII junior high school. The aspect of attractiveness and appropriateness of content were very eligible and it was followed by the aspects of function and difficulty level with eligible criteria while language aspect was fairly.

Table 2. The Result of Tryout (Big Group)

\begin{tabular}{llrrrrrl}
\hline No & Aspects & $\begin{array}{r}\text { Number of } \\
\text { items }\end{array}$ & $\begin{array}{r}\text { Positive } \\
\text { items }\end{array}$ & $\begin{array}{r}\text { Negative } \\
\text { items }\end{array}$ & Total & Avarage & Criteria \\
\hline 1 & Function & $1-10$ & 198 & 82 & 280 & 0.7 & Eligible \\
2 & Attractiveness & $11-20$ & 194 & 86 & 280 & 0.69 & Eligible \\
3 & Appropriateness & $21-30$ & 252 & 28 & 280 & 0.9 & Very eligible \\
& of content & & & & & & \\
4 & Language & $31-40$ & 152 & 128 & 280 & 0.54 & Fairly \\
5 & Difficulty Level & $41-50$ & 204 & 76 & 280 & 0.72 & Eligible \\
\hline & & TOTAL & & & 1400 & 0.71 & Eligible \\
\hline
\end{tabular}


Table 2 reports the result of tryout administered in class VIII C. There were 28 students participating in this tryout. It was done after the researcher revised the comic draft. The result presented in table 2 above shows that the average score was 0.7 . It means that local culture based digital comics are eligible to be used in the teaching of narrative reading comprehension. Five aspects involving function, the appropriateness of content, language, attractiveness, and level of difficulty have fulfilled the criteria.

Table 3. The Judgment of Material and Media Expert

\begin{tabular}{|c|c|c|c|c|}
\hline \multirow[b]{2}{*}{ No } & \multirow[b]{2}{*}{ Aspects } & \multicolumn{2}{|c|}{ Average } & \multirow[b]{2}{*}{ Category } \\
\hline & & $\begin{array}{l}\text { The Dance } \\
\text { Competition }\end{array}$ & $\begin{array}{c}\text { The Legend of } \\
\text { Banyuwangi }\end{array}$ & \\
\hline 1 & Instruction & 5 & 5 & Very eligible \\
\hline 2 & $\begin{array}{l}\text { Appropriateness of } \\
\text { content }\end{array}$ & 5 & 5 & Very eligible \\
\hline 3 & Language & 5 & 5 & Very eligible \\
\hline 4 & Graphic & 5 & 5 & Very eligible \\
\hline 5 & Presentation & 5 & 5 & Very eligible \\
\hline & Average & 5 & 5 & Very eligible \\
\hline
\end{tabular}

Table 3 shows that the average score of local based digital comic entitled The Dance Competition and The Legend of Banyuwangi was 5. There were five aspects measured namely instruction, appropriateness of content, language, graphic, and presentation. Those five aspects have fulfilled very eligible criteria. This result indicated that local based digital comics can be used in the teaching and learning process. Further, the judgment of the English teacher of SMPN 1 Kalipuro is presented in the following table.

Table 4. The Judgment of English Teacher

\begin{tabular}{llccl}
\hline No & \multicolumn{1}{c}{ Aspects } & \multicolumn{2}{c}{ Average } & Category \\
\cline { 3 - 4 } & & $\begin{array}{c}\text { The Dance } \\
\text { Competition }\end{array}$ & $\begin{array}{c}\text { The Legend of } \\
\text { Banyuwangi }\end{array}$ & \\
\hline 1 & Instruction & 5 & 5 & Very eligible \\
2 & $\begin{array}{l}\text { Appropriateness } \\
\text { of content }\end{array}$ & 5 & 5 & Very eligible \\
3 & Language & 5 & 5 & \\
4 & Graphic & 5 & 5 & Very eligible \\
5 & Presentation & 4.85 & 5 & Very eligible \\
\hline & Average & 4.97 & 5 & Very eligible \\
\hline
\end{tabular}

Table 4 shows that there is no difference between the judgment of English teacher and material and media expert. The average score of digital comic 
entitled The Dance Competition is 4.97 and The Legend of Banyuwangi is 5. The five aspects measured are very eligible to be used in the teaching and learning process, especially in the teaching of narrative reading comprehension in class VIII SMPN 1 Kalipuro, Banyuwangi.

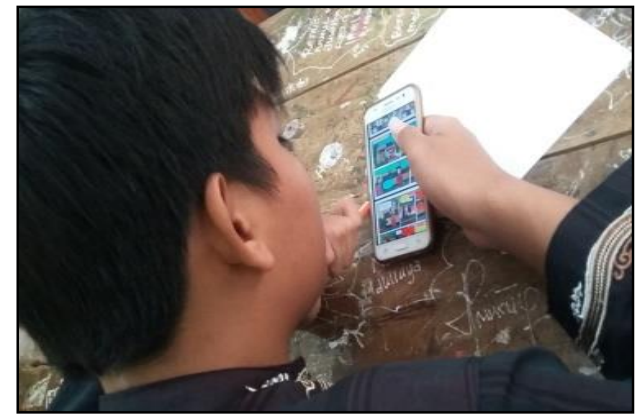

Picture 1. The student reads digital comic in the smartphone.

\section{Discussion}

\section{The Result of Need Analysis}

Based on the result of need analysis, the researcher identified a gap between the real condition of English language teaching in class VIII C of SMP Negeri 1 Kalipuro and the basic competences to be achieved. The implementation of narrative texts teaching and learning activity did not fit the standard competence and basic competences of reading skill. The narrative reading materials with a local culture touch were not found. Also, the reading materials were not related to the students' close environment whereas it is clearly stated from the school based curriculum to the revised edition of 2013 curriculum (K-13) that the teaching of English in Indonesia should be related with the students' closest environment in order that they can use English in a meaningful communication. This confirms what Prasetyo (2016) argued that Indonesia local culture which were found in English textbooks was limited on certain local folklore. Further, the lack of interesting media for reading narrative texts caused students difficult in comprehending narrative texts. In short, the results of need analysis reveal that the students need to be taught narrative texts with local culture content and a suitable interesting media in the form of digital comics.

\section{Developing Digital Comics with Local Culture Content}

Developing digital comics with local culture insertion into narrative reading materials were due to the need of providing students the materials which suit to their prior knowledge. This is important since the more experience the students have on a certain topic will result a good understanding the students can achieve on the related reading materials they read (Mishan, 2005). The products developed were in the form of local culture based digital comics. The materials 
focused on the narrative texts comprising two titles, which are title 1: The Dance Competition, and title 2: The Legend of Banyuwangi. The digital comics were developed by using Comic Creator software and were in the form of PDF files. The comics can be read in laptops, computers or smartphones. The local culture contents of Banyuwangi were inserted in every title of digital comics.

The first story told about the need of preserving Gandrung dance as the traditional dance of Banyuwangi. The story was started from the dance competition holding in SMPN 1 Kalipuro. The students were asked to participate in the competition. There were two groups of students taken in the story. The first group performed Korean dance while the second one performed traditional dance. Korean dance group was antagonist characters. They did many bad things to outperform the traditional group. However, they failed and the traditional dance group was the winner. The moral value of the digital comic entitled The Dance Competition was that it taught students about honesty and encouraged them to love traditional dance of Banyuwangi, Gandrung.

The second story told about the story of Sritanjung and Sidapeksa. The problem of the story happened when the king wanted to marry Sidapeksa's wife. The king cheated Sidapeksa by telling that his wife betrayed him. Then, Sidapekso got angry and killed his innocent wife. Because of the thing that she did not do, Sritanjung died and the water of the river where she died smelt good. The moral value of the digital comic entitled The Legend of Banyuwangi was that it taught students about honesty and loyalty. Also it introduced where the name of Banyuwangi came from.

\section{The Result of Expert Validation and Tryout}

From the first experts' judgment, the result of questionnaire showed that the average score of the judgment given by the material and media expert was 3.91 for the story entitled The Dance Competition and 3.88 for the story entitled The Legend of Banyuwangi. It meant that the quality of local culture based digital comics were enough in five aspects measured, namely, instruction, appropriateness of content, language, graphic, and presentation. The aspects of instruction and presentation were eligible. It meant that these two aspects were suitable with the target. On the other hand, the appropriateness of content, language and graphic were fairly eligible. It meant that these three aspects were good but there were several items to revise. Besides answering the questionnaire, the expert gave some comments and suggestion. He suggested that some pictures used in the comic entitled The Dance Competition were weird. The pictures of buildings, fence, and students' faces were not suitable with the local culture of Banyuwangi. Also, the color and model of uniform worn by the students need to revise. Further, the expert suggested adding one more character wearing Islamic uniform in the story. It was to represent the students in Banyuwangi who mostly wear a hair-dress. In the draft of comic entitled The Legend of 
Banyuwangi, the expert suggested revising the picture of fence and animals. The picture selection of animals should consider the geographical condition of Banyuwangi. On the other hand, from the English teacher judgment, the result of questionnaire showed that the average score of the judgment was eligible. The score of the comic entitled The Dance Competition was 4.37 and the comic entitled The Legend of Banyuwangi was 4.09 . The language aspect was very eligible followed by the aspect of content with eligible criteria. The aspects of instruction, graphic, and presentation were fairly eligible. It meant these criteria were good, but there were some items to revise. Further, the English teacher suggested revising the font size in both comics and some grammatical errors.

The first try out was administered to five selected students of class VIII C. In the try out, the researchers taught the digital comics to the students. During the process of reading, the researchers asked questions related to the content of comics to the students. The discussion was done to measure whether the students understood the content of comics. At the end of try out, the researchers distributed the questionnaire to the students. Based on the analysis, it was found that the average score of students' questionnaires was 0.78 . The score was in the interval between 0.60 to less than 0.80 . It meant that the digital comics were eligible.

The first revision of the product was done on the basis of the data obtained from the expert validation and try out. From the experts, the revision comprised grammatical, mechanic, and graphics. Besides, the instruction on how to read comics was added at the first part of comics. After revising the draft of digital comics, the researcher submitted the draft to the experts for the second validation. Based on the results of questionnaires given to the material and media expert, it was found that the average score of the comic entitled The Dance Competition and The Legend of Banyuwangi was 5 . It meant that the quality of local culture based digital comics were very eligible in five aspects measured, namely, instruction, appropriateness of content, language, graphic, and presentation.

Similarly, the result of questionnaire given to the English Teacher showed that the local culture based digital comics were very eligible to be used as learning materials in narrative text reading comprehension activities. The average score of the comic entitled The Dance Competition was 4. 97 and of the comic entitled The Legend of Banyuwangi was 5.

The second try out was conducted to all students of class VIII C. There were 28 students participating in the try out. Here, the researcher asked the students to read comics and discussed the content of comics. All students were enthusiastic to read the comics and able to answer the questions in the discussion. At the end of try out, the students gave their response to the questionnaire given. The results showed that the average score was 0.7 . It meant that the aspects of 
function, appropriateness of content, language use, attractiveness, and the difficulty level of material were eligible.

The research findings were in line with the results of previous research on developing digital comics for Bahasa Indonesia instruction conducted by Izza (2013) and Kustianingsari and Dewi (2016). The results showed that developing digital comics on Bahasa Indonesia instruction were eligible to be used as instructional media. The use of digital comics also improve the students' achievement.

\section{Conclusion}

The final product of this research and development is the local culture based digital comics comprising two titles, namely, The Dance Competition and The Legend of Banyuwangi. The results of data analysis gained form the experts' validation indicated that the local culture based digital comics were very eligible. The results gained from the students' try out also showed that these digital comics were eligible. Hence, it can be concluded that the local culture based digital comics are applicable for the students in terms of instructional function, appropriateness of content, language use, attractiveness, and the difficulty level of material.

In relation with the conclusion above, the English teacher and the eighth year students of Junior high school are suggested to use local culture based digital comics in the teaching and learning narrative text reading comprehension. Since the product was developed in limited number of titles, that is, there were only two titles of comics with Banyuwangi local culture content, it is suggested to develop digital comics by inserting the other local culture of Banyuwangi or the local culture that suit the students' learning context.

\section{Acknowledgement}

This research was supported and funded by DRPM 2017, Ministry of Research, Technology, and Higher Education, Indonesia. We thank English teachers of SMPN 1 Kalipuro, Banyuwangi and Prof. Bambang Yudi Cahyono, P.hD. from Universitas Negeri Malang for comments that greatly improved the quality of digital comics. We would also like to show our gratitude to students of class VIII C of SMPN 1 Kalipuro, Banyuwangi for excellent participation during this research. Also, we thank our colleagues from Universitas PGRI Banyuwangi who provided insight and expertise that greatly assisted the research. In addition, our gratitude is addressed to the committee of The 9th NELTAL Conference, Universitas Negeri Malang for giving us opportunity to present and share the research result. 


\section{References}

Abdel-Hack \& Helwa. (2014). Using Digital Story Telling and Webblogs Instruction to Enhance EFL Narrative Writing and Critical Thinking Skills among EFL Majors at Faculty of Education. International Research Journals, 5(1): 8-41. https://doi.org/10.14303/er.2014.011.

Borg, W.R. \& Gall, M.D. (1983). Educational Research an Introduction. New York: Longman.

Cahyono. B.Y. \& Megawati. A. (Eds). (2013). Materials and Media in English Language Teaching. Malang: State University of Malang Press.

Clandfield, L. 2008. Culture in ELT. TESL of Ontario. 34(3): 1 - 8. Retrieved from http://www.teslontario.org/uploads/publications/contact/ContactSummer2008.pdf

Genc, B. \& Bada, E. (2005) Culture in Language Learning and Teaching. The Reading Matrix. 5 (1): 73 - 84. Retrieved from http://www.readingmatrix.com/articles/genc_bada/article.pdf.

Ivanovzka. B. (2015). Learner Autonomy in Foreign language Education and in Cultural Context. Procidea-Social and Behavioural Sciences, 180, 352-356. https://doi.org/10.1016/j.sbspro.2015.02.128

Izza, T. (2013). Pengembangan Media Pembelajaran Komik Digital Bahasa Indonesia untuk Meningkatkan Kemampuan Menulis Cerita Pendek (Cerpen) Kelas IX Semester Ganjil di SMP Negeri 4 Malang. (Undergraduate Thesis, Universitas Negeri Malang). Retrieved from http://karya-ilmiah.um.ac.id/index.php/TEP/article/view/26206

Kustianingsari, N. \& Dewi, U. (2016). Pengembangan Media Komik Digital pada Mata Pelajaran Bahasa Indonesia Tema Lingkungan Sahabat Kita Materi Teks Cerita Manusia dan Lingkungan untuk Siswa Kelas V SDN Putat Jaya III/ 379 Surabaya. Retrieved from http:www.ejournal.unesa.ac.id/article/16881/12/article.pdf

Mishan, F. (2005). Designing Authenticity into Language Learning Materials. Oregon: Intellect. Ltd.

Nguyen, C. T. (2011). Impacts of Socio-culture on the Development of Autonomous Learning: a Lens of Vietnamese Context. Journal of Studies in Education, 1(1): 1-10. https://doi.org/10.5296/jse.vlil.866

Prasetyo, A. (2016). Folklore in EFL: The Local Wisdom Implementation of Indonesian Curriculum. Journal of ELT Research. 1(2): 60-65. https://doi.org/10.22236/JER_Vol1 lssue2pp60-65.

Ravelo, L. C. (2013). The Use of Comic Strips as a Means of Teaching History in the EFL Class: Proposal of Activities Based on Two Historical Comic Strips Adhering to the Principles of CLIL. Latin America Journal of Content and Language Integrated Learning, 6(1): 1-19. https://doi.org/105294/laclil.2013.6.1.1

Richards, J. C. (2001). Curriculum Development in Language Teaching. Cambridge: Cambridge University Press.

Royani, M. (2012). The Use of Local Culture Texts for Enthusiastic English Reading Teaching. The International Journal of Social Sciences, 7(1): $130-135$. Retrieved 
from https://www.tijoss.com/7th\%20volume/Miftah.pdf

Song, L. (2010). The Role of Context in Discourse Analysis. Journal of Language Teaching and Research. 1(6): 876-879. https://doi.org/104304/jltr.1.6.876-879

Xu, Z. (2013). Globalization, Culture and ELT Materials: A Focus on China. Multilingual Education. 3(6) 2 - 9. https://doi.org/10.1186/2191-5059-3-6

\section{Appendix}

\section{The Result of Need Analysis Questionnaire}

\begin{tabular}{|c|c|c|c|c|c|c|}
\hline \multirow{4}{*}{$\begin{array}{l}\text { No } \\
1\end{array}$} & \multirow{4}{*}{$\begin{array}{l}\text { Statements } \\
\text { Do you use OHP, LCD, } \\
\text { laptop, etc. for reading } \\
\text { English texts? }\end{array}$} & \multicolumn{4}{|c|}{ Options (\%) } & \multirow{4}{*}{$\begin{array}{l}\text { Total (\%) } \\
35 \\
(100 \%)\end{array}$} \\
\hline & & Very often & Often & Seldom & Never & \\
\hline & & 0 & 5 & 25 & 5 & \\
\hline & & $0 \%$ & $14.29 \%$ & $71.43 \%$ & $14.29 \%$ & \\
\hline \multirow[t]{3}{*}{2} & \multirow{3}{*}{$\begin{array}{l}\text { I use pictures for reading } \\
\text { English texts }\end{array}$} & Very often & Often & Seldom & Never & \multirow{3}{*}{$\begin{array}{l}35 \\
(100 \%)\end{array}$} \\
\hline & & 2 & 3 & 21 & 9 & \\
\hline & & $5.71 \%$ & $8.57 \%$ & $60 \%$ & $25.71 \%$ & \\
\hline \multirow[t]{3}{*}{3} & \multirow[t]{3}{*}{$\begin{array}{l}\text { I use this media when I } \\
\text { read narrative texts }\end{array}$} & Puppet & Film & $\begin{array}{l}\text { Music/so } \\
\text { ngs }\end{array}$ & others & \multirow[t]{3}{*}{$\begin{array}{l}35 \\
(100 \%)\end{array}$} \\
\hline & & 3 & 16 & 14 & 2 & \\
\hline & & $8.57 \%$ & $45.71 \%$ & $40 \%$ & $5.71 \%$ & \\
\hline \multirow[t]{3}{*}{4} & \multirow{3}{*}{$\begin{array}{l}\text { Are comics used as } \\
\text { narrative texts resources? }\end{array}$} & Very often & Often & Seldom & Never & \multirow{3}{*}{$\begin{array}{l}35 \\
(100 \%)\end{array}$} \\
\hline & & 4 & 2 & 24 & 5 & \\
\hline & & $11.43 \%$ & $5.71 \%$ & $68.57 \%$ & $14.29 \%$ & \\
\hline \multirow[t]{3}{*}{5} & \multirow{3}{*}{$\begin{array}{l}\text { I learn narrative texts in } \\
\text { students' worksheets only. }\end{array}$} & Very often & Often & Seldom & Never & \multirow{3}{*}{$\begin{array}{l}35 \\
(100 \%)\end{array}$} \\
\hline & & 6 & 15 & 11 & 3 & \\
\hline & & $17.14 \%$ & $42.86 \%$ & $31.43 \%$ & $8.57 \%$ & \\
\hline \multirow[t]{3}{*}{6} & \multirow{3}{*}{$\begin{array}{l}\text { I use electronic books for } \\
\text { learning English. }\end{array}$} & Very often & Often & Seldom & Never & \multirow{3}{*}{$\begin{array}{l}35 \\
(100 \%)\end{array}$} \\
\hline & & 3 & 7 & 19 & 6 & \\
\hline & & $8.57 \%$ & $20 \%$ & $54.29 \%$ & $17.14 \%$ & \\
\hline \multirow[t]{4}{*}{7} & \multirow{4}{*}{$\begin{array}{l}\text { I like using electronic } \\
\text { media better than using } \\
\text { textbooks when I read } \\
\text { English texts. }\end{array}$} & Strongly & Agree & Disagree & Strongly & \multirow{4}{*}{$\begin{array}{l}35 \\
(100 \%)\end{array}$} \\
\hline & & Agree & & & disagree & \\
\hline & & 6 & 15 & 14 & 0 & \\
\hline & & $17.14 \%$ & $42.86 \%$ & $40 \%$ & $0 \%$ & \\
\hline \multirow[t]{3}{*}{8} & I use a dictionary to & Very often & Often & Seldom & Never & \multirow{3}{*}{$\begin{array}{l}35 \\
(100 \%)\end{array}$} \\
\hline & comprehend narrative & 13 & 17 & 5 & 0 & \\
\hline & texts. & $37.14 \%$ & $48.57 \%$ & $14.29 \%$ & $0 \%$ & \\
\hline \multirow[t]{4}{*}{9} & The use of media in & Strongly & Agree & Disagree & Strongly & \multirow[t]{4}{*}{$35(100 \%)$} \\
\hline & \multirow{3}{*}{$\begin{array}{l}\text { English class helps me } \\
\text { comprehend narrative } \\
\text { texts. }\end{array}$} & Agree & & & disagree & \\
\hline & & 9 & 20 & 5 & 1 & \\
\hline & & $25.71 \%$ & $57.14 \%$ & $14.29 \%$ & $2.86 \%$ & \\
\hline
\end{tabular}




\begin{tabular}{|c|c|c|c|c|c|c|}
\hline \multirow{2}{*}{$\begin{array}{l}\text { No } \\
10\end{array}$} & \multirow{4}{*}{$\begin{array}{l}\text { Statements } \\
\text { Are fairytales entitled } \\
\text { Cinderella, Snow White, } \\
\text { Rapunzel, etc. used for } \\
\text { narrative reading material? }\end{array}$} & \multicolumn{4}{|c|}{ Options (\%) } & \multirow{2}{*}{$\begin{array}{l}\text { Total (\%) } \\
35(100 \%)\end{array}$} \\
\hline & & Very often & Often & Seldom & Never & \\
\hline & & 2 & 10 & 17 & 6 & \\
\hline & & $5.71 \%$ & $28.57 \%$ & $48.57 \%$ & $17.14 \%$ & \\
\hline \multirow[t]{3}{*}{11} & \multirow{3}{*}{$\begin{array}{l}\text { Are fables used for } \\
\text { narrative reading } \\
\text { materials? }\end{array}$} & Very often & Often & Seldom & Never & \multirow[t]{3}{*}{$35(100 \%)$} \\
\hline & & 2 & 12 & 19 & 2 & \\
\hline & & $5.71 \%$ & $34.29 \%$ & $54.29 \%$ & $5.71 \%$ & \\
\hline \multirow[t]{3}{*}{12} & \multirow{3}{*}{$\begin{array}{l}\text { I read narrative texts about } \\
\text { Banyuwangi culture in } \\
\text { English class. }\end{array}$} & Very often & Often & Seldom & Never & \multirow[t]{3}{*}{$35(100 \%)$} \\
\hline & & 2 & 7 & 23 & 3 & \\
\hline & & $5.71 \%$ & $20 \%$ & $65.71 \%$ & $8.57 \%$ & \\
\hline \multirow[t]{4}{*}{13} & \multirow{4}{*}{$\begin{array}{l}\text { The story about } \\
\text { Banyuwangi culture is } \\
\text { interesting to read }\end{array}$} & Strongly & Agree & Disagree & Strongly & \multirow[t]{4}{*}{$35(100 \%)$} \\
\hline & & Agree & & & disagree & \\
\hline & & 22 & 10 & 3 & 0 & \\
\hline & & $62.86 \%$ & $28.57 \%$ & $8.57 \%$ & $0 \%$ & \\
\hline \multirow[t]{4}{*}{14} & \multirow{4}{*}{$\begin{array}{l}\text { Narrative texts that I read } \\
\text { in the class are very } \\
\text { difficult. }\end{array}$} & Strongly & Agree & Disagree & Strongly & \multirow[t]{4}{*}{$35(100 \%)$} \\
\hline & & Agree & & & disagree & \\
\hline & & 2 & 10 & 21 & 2 & \\
\hline & & $5.71 \%$ & $28.57 \%$ & $60 \%$ & $5.71 \%$ & \\
\hline \multirow[t]{3}{*}{15} & \multirow{3}{*}{$\begin{array}{l}\text { Before reading I set a goal } \\
\text { (ex: for finding information, } \\
\text { for entertainment etc.) }\end{array}$} & Very often & Often & Seldom & Never & \multirow[t]{3}{*}{$35(100 \%)$} \\
\hline & & 2 & 16 & 16 & 0 & \\
\hline & & $8.57 \%$ & $45.71 \%$ & $45.71 \%$ & $0 \%$ & \\
\hline \multirow[t]{3}{*}{16} & \multirow{3}{*}{$\begin{array}{l}\text { I use reading strategies } \\
\text { when reading texts }\end{array}$} & Very often & Often & Seldom & Never & \multirow{3}{*}{$\begin{array}{l}35 \\
(100 \%)\end{array}$} \\
\hline & & 7 & 16 & 12 & 0 & \\
\hline & & $20 \%$ & $45.71 \%$ & $34.29 \%$ & $0 \%$ & \\
\hline \multirow[t]{3}{*}{17} & \multirow{3}{*}{$\begin{array}{l}\text { Before reading, I guess } \\
\text { the topic of the texts. }\end{array}$} & Very often & Often & Seldom & Never & \multirow[t]{3}{*}{$35(100 \%)$} \\
\hline & & 4 & 11 & 17 & 3 & \\
\hline & & $11.43 \%$ & $31.43 \%$ & $48.57 \%$ & $8.57 \%$ & \\
\hline \multirow[t]{3}{*}{18} & \multirow{3}{*}{$\begin{array}{l}\text { When I am reading, I } \\
\text { check whether my } \\
\text { prediction before reading } \\
\text { is correct. }\end{array}$} & Very often & Often & Seldom & Never & \\
\hline & & 8 & 6 & 16 & 5 & $(100 \%)$ \\
\hline & & $22.86 \%$ & $17.14 \%$ & $45.71 \%$ & $14.29 \%$ & \\
\hline 19 & I translate every sentence & Very often & Often & Seldom & Never & $35(100 \%)$ \\
\hline & for comprehending the & 9 & 15 & 9 & 2 & \\
\hline & texts I read? & $25.71 \%$ & $42.86 \%$ & $25.71 \%$ & $5.71 \%$ & \\
\hline 20 & I know about the elements & Strongly & Agree & Disagree & Strongly & 35 \\
\hline & of plot in narrative texts & Agree & & & disagree & $(100 \%)$ \\
\hline & (ex: characters, character & 3 & 13 & 17 & 2 & \\
\hline & $\begin{array}{l}\text { trait, time and setting, } \\
\text { problem, and resolution)? }\end{array}$ & $8.57 \%$ & $37.14 \%$ & $48.57 \%$ & $5.71 \%$ & \\
\hline
\end{tabular}




\begin{tabular}{|c|c|c|c|c|c|c|}
\hline \multirow{2}{*}{$\begin{array}{l}\text { No } \\
21\end{array}$} & \multirow{4}{*}{$\begin{array}{l}\text { Statements } \\
\text { The teacher introduces the } \\
\text { topic of the text before the } \\
\text { teaching and learning } \\
\text { process starts? }\end{array}$} & \multicolumn{4}{|c|}{ Options (\%) } & \multirow{3}{*}{$\begin{array}{l}\text { Total (\%) } \\
35\end{array}$} \\
\hline & & Very often & Often & Seldom & Never & \\
\hline & & 11 & 14 & 6 & 4 & \\
\hline & & $31.43 \%$ & $40 \%$ & $17.14 \%$ & $11.43 \%$ & \\
\hline \multirow[t]{4}{*}{22} & \multirow{4}{*}{$\begin{array}{l}\text { The teacher explains } \\
\text { narrative texts clearly. }\end{array}$} & Strongly & Agree & Disagree & Strongly & $35(100 \%)$ \\
\hline & & Agree & & & disagree & \\
\hline & & 4 & 19 & 8 & 4 & \\
\hline & & $11.43 \%$ & $54.29 \%$ & $22.86 \%$ & $11.43 \%$ & \\
\hline \multirow[t]{3}{*}{23} & \multirow{3}{*}{$\begin{array}{l}\text { The teacher guides me } \\
\text { when I am reading } \\
\text { narrative texts. }\end{array}$} & Very often & Often & Seldom & Never & $35(100 \%)$ \\
\hline & & 11 & 21 & 2 & 1 & \\
\hline & & $31.43 \%$ & $40 \%$ & $5.71 \%$ & $2.86 \%$ & \\
\hline \multirow[t]{3}{*}{24} & \multirow{3}{*}{$\begin{array}{l}\text { After reading narrative } \\
\text { texts, I answer } \\
\text { comprehension questions } \\
\text { related to texts }\end{array}$} & Very often & Often & Seldom & Never & $35(100 \%)$ \\
\hline & & 4 & 14 & 14 & 2 & \\
\hline & & $11.43 \%$ & $40 \%$ & $40 \%$ & $5.71 \%$ & \\
\hline \multirow[t]{3}{*}{25} & The teacher give & Very often & Often & Seldom & Never & $35(100 \%)$ \\
\hline & feedbacks to me, such as & 6 & 16 & 7 & 6 & \\
\hline & $\begin{array}{l}\text { comments, scores, } \\
\text { appraisal after I read } \\
\text { narrative texts }\end{array}$ & $17.14 \%$ & $45.71 \%$ & $20 \%$ & $17.14 \%$ & \\
\hline
\end{tabular}

